\title{
From epic wildfires to epic flash floods: Rethinking environ- mental planning in an era of extremes
}

${ }^{1}$ University of California Berkeley, Social Science Matrix - Center for Catastrophic Risk Management, 820 Social Science Building, Berkeley, California, USA.

2 University of California Berkeley, College of Environmental Design, Wurster Hall, Berkeley, California, USA.

*Correspondence: annaserrallobet@berkeley.edu

\begin{abstract}
On January 9, 2018, a series of debris flows killed 23 people and caused over a $\$ 1$ billion in economic losses in Montecito, Santa Barbara County, California. The debris flows followed a classic pattern in mountainous areas of southern California: A large wildfire (the 2017 Thomas Fire) burned the headwaters of streams draining the Transverse Ranges southward to the Pacific. A cell of intense rain fell on hydrophobic soils in the burn area, generating debris flows that propagated downstream, affecting areas along the stream channels. The 2018 Montecito debris flows raise compelling questions about the role of scientific information in decision making generally, and specifically how hazardous areas along rivers and streams are mapped, how land use is regulated in these zones, and how best to respond in emergency situations. We analyze the evolution of urban development in these flood hazard areas since the beginning of the 20th century, the recovery planning strategies that the local government adopted after the event, and the role of post-fire debris flow maps in environmental planning. We highlight the importance of exposure as a key element to reduce risk.
\end{abstract}

Keywords: floods after fires; debris flows; environmental planning, Montecito, California. floods: Rethinking environmental planning in an era of extremes. SUPTM 2022 conference proceedings sciforum-056822.

https://doi.org/10.31428/10317/10606

Publisher's Note: UPCT and Sciforum stays neutral with regard to jurisdictional claims in published maps and institutional affiliations.

Copyright: (c) 2022 by the authors. Submitted for possible open access publication under the terms and conditions of the Creative Commons Attribution (CC BY) license (https://creativecommons.org/license s/by/4.0/).

\section{Introduction}

Floods after fires are becoming a big concern in Mediterranean climate regions such as California or the southern parts of Europe. Fires can intensify the magnitude of floods creating a hydrophobic layer in the soil which can reduce infiltration during a storm, which can create flash floods. However, wildfires and flash floods are not a risk per se, they become a risk when we put ourselves in harm's way, for example building in high hazard areas. For example, the 2018 debris flows in Montecito (California) occurred less than one month after the Thomas fire, which was the biggest fire in the history of California at that time. The debris flows killed 23 people, damaged or destroyed 558 buildings (CAL FIRE, 2018) and caused over $\$ 1$ billion in direct damages (Lancaster et al. 2021). This type of disaster is likely to become more common with climate change but also because of current urbanization trends in flood hazard areas. We analyzed the 2018 debris flow in Montecito to better understand what type of information is used in the US to inform land use planning decisions in alluvial fans and what are the main challenges to improve current practices. 


\section{Area of study}

Montecito, an unincorporated community east of Santa Barbara, has alluvial-fan landforms sloping south from the Santa Ynez Mountain front down to the gently-sloping coastal plain along the Pacific Ocean. Between the mountains and the coast is a swath of urbanized land, traversed by streams (oriented N-S) and two major roads, Highways 101 and 192, oriented E-W. Debris flows after wildfires are common in Southern California, reoccurring on time scales of 30-65 years (Keller et al., 2020).

\section{Methods}

To understand the role of debris flow maps in environmental planning and highlight the importance of exposure as a key element of risk we:

- Analyzed how official FEMA (riverine) flood hazard maps have evolved over time in Montecito

- Quantified the exposure evolution in an extended flood hazard area using Sanborn (Fire) Insurance Maps from 1918, 1942, aerial imagery from 19701971, NAIP Imagery from 2016, and a GIS data layer with the structures from 2016 provided by Santa Barbara County (Lee et al. 2021).

- Compared the current FEMA maps used to inform land use planning decisions in Montecito (the 2018 Flood Insurance Rate Map, FIRM, and the FEMA "recovery" map) with the California Geological Survey post-fire debris flow hazard areas map developed in 2018.

\section{Results}

\subsection{Evolution of houses in flood hazard areas since the beginning of the 20th century}

Debris flows after fires are common in Montecito (Keller, 2020; Gurrola and Rogers, 2021). The problem is that exposure in hazard zones has increased substantially in the last decades. Since 1900 there have been six debris flows and debris-laden floods after fires in Montecito (1914, 1926, 1964, 1969, 1971 and 2018, 2019) (Gurrola and Rogers, 2020 ), which have caused significant property damages, and on some occasions, loss of lives.

Over the last 50 years, the number of structures in the extended flood hazard area has almost doubled in Montecito (Lee et al. 2021), even after Santa Barbara County joined the NFIP in 1979. This is because in the US - unlike some European countries such as France or Spain - under the National Flood Insurance Program (NFIP) developments in high hazard zones depicted in the Flood Insurance Rate Maps (FIRMs) are highly discouraged but not explicitly prohibited as national policy. Any prohibition on rebuilding in the path of historical (or predicted) debris flows must be implemented at the local government level.

\subsection{The recovery planning}

After this event, Santa Barbara County decided to facilitate the reconstruction of all the structures in Montecito impacted by the 2018 event, even if they were located inside the current regulatory flood hazard area (called the Special Flood Hazard Area or SFHA). 
We document that the area mapped as being in the flood hazard footprint (SFHA) 1 in the FIRMs has decreased considerably in the last 50 years. However, the reduced area 2 of the SFHA does not necessarily imply that the risk has reduced. In fact, during the 3 2018 Montecito debris flow, of the 558 structures damaged, more than $60 \%$ were outside 4 of the SFHA (Kean et al. 2019). This is related to the fact that the FIRMs are made using 5 assumptions of conventional riverine flooding processes. However, Montecito is built on 6 alluvial fans. Flood flows on alluvial fans are complex, involving very high sediment loads, debris flows, and frequent switching of channels (avulsion) and debris flows. FIRMs are made using clear water models and assumptions that don't encapsulate the complexity of alluvial fan behavior.

Aware of the limitations of using FIRMs to manage areas built on alluvial fans, FEMA created another map in 2018 showing flood water depth (100y) and using assumptions that try to reproduce the behavior of debris flows (e.g. assuming that culverts and bridges will be clogged with debris and water will overtop these structures), although it is still based on clear water models. This map is known as the "FEMA recovery map". This map did not replace the effective FIRM but was intended to inform the recovery process (e.g. requiring building codes for the reconstruction beyond the FIRM boundaries), recognizing that most of the houses destroyed were located outside of the Special Flood Hazard Area.

\subsection{The role of post-fire debris flow maps in environmental planning}

Riverine flooding is commonly mapped using clear water models. But debris flow maps are based on sediment transport models. They can also take into account the influence of fire on floods. And they can be dynamic maps, looking at the changes in the landscape as the soil recovers after a fire. And we can also use historical maps and geomorphological information to complement the models. The California Geological Survey is now developing this type of "process-based" maps, but they are not yet used for land use planning decisions, they are only used for evacuation planning.

\section{Conclusion}

In light of this results our main recommendation for the community of Montecito is to change from form-based policy to process-based policy by: (1) replacing the effective FIRM based on clear water (riverine flooding model) with the California Geological Survey post-fire debris flow hazard map (an alluvial fan flooding approach) created in 2018 using sediment transport models, historical and geomorphological information, and (2) reclassifying land use in high hazard zones to stop the trend of rebuilding in zones that have been repeatedly impacted by destructive flash floods and debris flows.

Funding: France-Berkeley Fund

Conflicts of Interest: The authors declare no conflict of interest.

1. CAL FIRE (California Department of Forestry and Fire Protection) (2018). Thomas Fire 845 Watershed Emergency Response Team - Final Report: CA-VNC-103156, 172 p. 
2. Gurrola, L.D., Rogers, J. D. (2020). Geologic Hazards Due to Landslide Dams in the Cold Springs and Hot Springs 1 Watersheds, County of Santa Barbara, California; Geological Society of America Abstracts with Programs. Vol. 52, 2 No. 4, May 2020.

3. Gurrola, L.D., Rogers, J. D. (2021). Flood and Debris Flow History of the Montecito Watersheds, Santa Barbara County, California The Project for Resilient Communities (TPRC).

4. Kean, J.W., Staley, D.M., Lancaster, J.T., Rengers, F.K., Swanson, B.J., Coe, J.A., Hernandez, J.L., Sigman, A.J., Allstadt, K.E., and Lindsay, D.N., (2019). Inundation, flow dynamics, and damage in the 9 January 2018 Montecito debris-flow event, California, USA: Opportunities and challenges for post-wildfire risk assessment: Geosphere, v. 15, no. X, p. 1-24, https://doi.org/10.1130/GES02048.1.

5. Keller, E., Adamaitis, C., Alessio, P., Goto, E., and Gray, S. (2020). Montecito debris flows of 9 January 2018: Physical processes and social implications, in Heermance, R.V., and Schwartz, J.J., eds., From the Islands to the Mountains: A 2020 View of Geologic Excursions in Southern California: Geological Society of America Field Guide 59, p. 95114.

6. Lancaster, J. T., Swanson, B. J., Lukashov, S. G., Oakley, N. S., Lee, J. B., Spangler, E. R., et al. (2021). Observations and analyses of the 9 January 2018 debris-flow disaster, Santa Barbara County, California. Environmental and Engineering Geoscience, 27(1), 3-27. https://doi.org/10.2113/EEG-D-20-00015

7. Lee YC, Bilginsoy, A., Chen, Y., Clark, D., Dickenson, A., Harris K., Wang, X., Wright, S., Serra-Llobet, A., Radke, J., Lindbergh, S., Kondolf, G.M. (2021). Using Historical Information to Inform Planning for Floods after Fires. Report from student research project undertaken in class, Environmental Planning Studio, UC Berkeley, April-May 2020. Winner of ASFPM Foundation 11th Annual Student Paper Competition. 